\title{
Oral Supplementation of $\beta$-Carotene Benefits the Hepatic Structure and Metabolism in Mice (Mus musculus) Exposed to A Chronic Ethanol Consumption
}

(Suplemen Oral $\beta$-Karotena Bermanfaat kepada Struktur Hepatik dan Metabolisme Tikus (Mus musculus) Terdedah kepada Penggunaan Etanol Kronik)

\section{Cristian Sandoval*, Bélgica Vásquez, Adriana Vasconcellos, Vanessa Souza-Mello, Khosrow Adeli, Carlos Mandarim-De-LaCerda\& Mariano Del Sol}

\begin{abstract}
Ethanol cannot be excreted and must be metabolized in the liver. Alcoholic liver disease is a blanket term for conditions related specifically to the liver and alcohol use. The study aimed to evaluate the metabolic, biochemical and histological effects of the oral supplementation with $\beta$-carotene on the liver of C57BL/6 mice exposed to ethanol consumption. Thirty male C57BL/6 mice (Mus musculus) were divided into six experimental groups: Control (C), Lowdose alcohol (LA), Moderate-dose alcohol (MA), $\beta$-carotene (B), Low-dose alcohol $+\beta$-carotene $(L A+B)$ and Moderate-dose alcohol $+\beta$-carotene $(M A+B)$ group. One-way ANOVA was used. The greatest intake of calories was noted in the LA (65.4 $\pm 12.5 \mathrm{~kJ})$ and $M A(68.6 \pm 18.6 \mathrm{~kJ})$ groups. The $L A+B$ and $M A+B$ groups shown an improvement in the HOMA-IR index $\left(8.7 \pm 2.4\right.$ and $6.7 \pm 3.5$, respectively), increased $A D H$ levels $\left(16.2 \pm 1.6\right.$ and $18.9 \pm 0.5 \mathrm{pmol} / \mathrm{minm}^{-1}$, respectively) and decreased insulin levels (14.0 \pm 3.3 and $10.6 \pm 5.7 \mu \mathrm{UmL}^{-1}$, respectively). It was also observed that oral supplementation with $\beta$-carotene improved the hepatic parenchyma in the $L A+B$ group, showing normal-sized hepatocytes, whereas in the MA+B group it relieved the structural damage, revealing fewer lipid droplets than the MA group.
\end{abstract}

Keywords: Alcohol abuse; alcoholic liver disease; antioxidants; antioxidant effects

ABSTRAK

Etanol tidak boleh diekspresikan dan mesti dimetabolisme di dalam hati. Penyakit hati alkohol adalah istilah selimut untuk keadaan yang berkaitan secara khusus dengan penggunaan hati dan alkohol. Kajian ini bertujuan untuk menilai kesan metabolik, biokimia dan histologi suplemen dengan $\beta$-karotena pada hati tikus C57BL/6 yang terdedah kepada pengambilan etanol. Tiga puluh tikus C57BL/6 lelaki (Mus musculus) dibahagikan kepada enam kumpulan uji kaji: Kawalan (C), alkohol dos rendah (LA), alkohol dos sederhana (MA), $\beta$-karotena (B), alkohol dos rendah + kumpulan $\beta$-karotena $(L A+B)$ dan alkohol dos sederhana $+\beta$-karotena $(M A+B)$. ANOVA sehala telah digunakan. Pengambilan kalori paling banyak dicatat dalam kumpulan LA $(65.4 \pm 12.5 \mathrm{~kJ})$ dan MA $(68.6 \pm 18.6 \mathrm{~kJ})$. Kumpulan $\mathrm{LA}+B$ dan MA+B menunjukkan peningkatan dalam indeks HOMA-IR $(8.7 \pm 2.4$ dan $6.7 \pm 3.5)$, peningkatan kadar ADH (16.2 \pm 1.6 dan $18.9 \pm 0.5 \mathrm{pmol} /$ minitm $\left.^{-1}\right)$ dan penurunan tahap insulin $\left(14.0 \pm 3.3\right.$ dan $\left.10.6 \pm 5.7 \mu U_{m L^{-1}}\right)$. Juga diperhatikan bahawa suplemen dengan $\beta$-karotena meningkatkan parenkima hepatik pada kumpulan LA+B, menunjukkan hepatosit berukuran normal, sedangkan dalam kumpulan $M A+B$ ia melegakan kerosakan struktur, menunjukkan lebih sedikit titisan lipid daripada kumpulan MA.

Kata kunci: Antioksidan; kesan antioksidan; penderaan alkohol; penyakit hati alkohol

\section{INTRODUCTION}

Alcohol consumption and its toxic effects have been increasing in recent decades, creating with it a great socioeconomic and health burden (Schwartz \& Reinus 2012). Ethanol cannot be excreted and must be metabolized, primarily by the liver, causing a wide range of hepatic alterations. Alcoholic liver disease (ALD) encompasses a broad spectrum related specifically to the liver and alcohol use. The most prevalent types of ALD are fatty liver, alcoholic hepatitis and cirrhosis. Often, as people continue to drink heavily, the progression from fatty liver to hepatitis to cirrhosis in the long term is common. 
Primarily oxidative pathways mediate ethanol metabolism through the enzymes ethanol dehydrogenase (EtOH) and aldehyde dehydrogenase (ALDH). Alternatively, it travels via non-oxidative pathways (Clugston \& Blaner 2012). Hence, the resulting oxidative stress and tissue damage can impair liver structure and function. The activation of xanthine oxidase and NADPH oxidase increases reactive oxygen species (ROS) levels, favoring lipid peroxidation, hepatic catabolism of vitamin A and the progression of ALD (Albano 2008).

Of note, lipid peroxidation can enhance the inner mitochondrial membrane permeability and impair the oxidative phosphorylation reactions (Zakhari \& Li 2007), ending in ballooning degeneration and necrotic lesions within the hepatocytes, inducing apoptosis by the release of cytochrome C (Ronis et al. 2010). Moreover, ROS reduces the mitochondrial pool of reduced glutathione (GSH) while stimulating TNF- $\alpha$ release, both of which enhance the susceptibility of hepatic tissue to oxidative damage and fibrosis (Fernandez-Checa \& Kaplowitz 2005).

Antioxidants can counteract the damage stemming from excessive ROS at the cellular level through the activation of some enzymatic or non-enzymatic pathways (Chang et al. 2005). The augmentation of GSH reduces the ROS by detoxifying the hydrogen peroxide and other organic peroxide produced in the mitochondria, whereas the action of some vitamins and pro-vitamins, such as vitamins $C$ and $E$ and the carotenoids like $\beta$-carotene, helps eliminate free radicals (Nieto 2007).

Although excess preformed vitamin A -hypervitaminosis A- can have significant toxicity, large amounts of $\beta$-carotene and other provitamin A carotenoids have not been associated with adverse effects (Grune et al. 2010). However, the manifestations of hypervitaminosis A includes increased intracranial pressure (pseudotumor cerebri), dizziness, nausea, headaches, skin irritation, pain in joints and bones, coma, and even death (Institute of Medicine, Food and Nutrition Board 2001; Ross 2010; Solomons 2006). In effect, when people consume too much vitamin A, their tissue levels take a long time to fall after they discontinue their intake, and the resulting liver damage is not always reversible. On the other hand, there are no known clinical effects of consuming low vitamin A or carotenes diets in short term. However, studies of carotene-deficient diets reported an increased oxidative susceptibility (Dixon et al. 1998, 1994; Lin et al. 1998), but there are still have an uncertain relevance with regard to clinical outcomes.

Dietary retinoids are vital to maintaining physiological processes and are mostly located within the liver as retinyl esters (RE). Alterations in the fatty acyl profile of RE are an early marker of alcohol consumption and liver damage (Clugston \& Blaner 2012). Different mechanisms protect the hepatocyte against oxidative stress, but increased GSH levels in the liver emerge as the main target of therapeutic approaches. Given that the supplemented GSH or cysteine (GSH precursor) cannot enter the hepatocyte, experimental studies have been using $\beta$-carotene supplementation, as this can maximize the antioxidant activity by increasing the GSH concentrations (Lin et al. 2009). In effect, there is evidence that $\beta$-carotene supplementation increases GSH concentration via stimulating GSH synthetase activity. Previous studies have shown that $\beta$-carotene supplementation was able to prevent the ethanolinduced decline in GSH in the present through increased intracellular GSH levels (Lin et al. 2009; Takeda et al. 2008). These studies suggest that it might be attributable to a stimulating GSH synthetase activity induced by $\beta$-carotene. Therefore, GSH synthetase activity must be determined in future studies.

Thus, $\beta$-carotene supplementation can be a viable strategy to reduce the liver damage caused by excessive alcohol intake and to impede the ALD from progressing to more harmful diseases (Sandoval et al. 2019). Nevertheless, although $\beta$-carotene is thought to be less dangerous, it can also have toxic effects on the liver of patients who continue consuming ethanol (Leo et al. 1992). In addition, $\beta$-carotene increases the risk of lung cancer in smokers (Alpha-Tocopherol, Beta Carotene Cancer Prevention Study Group 1994). This is important because most smokers also drink ethanol, and researchers have discovered that the increased risk of lung cancer after therapy with $\beta$-carotene is related to concurrent ethanol consumption in smokers (Albanes et al. 1996).

In addition, tests on the effectiveness of $\beta$-carotene supplementation for the treatment of alcoholic hepatopathies are contradictory, and it has not been possible to confirm its therapeutic action (Bjelakovic et al. 2011). Studies have shown that ethanol interferes with its conversion to vitamin A, whereas others have reported that moderate alcohol ingestion may result in an increase in the $\beta$-carotene concentrations when this is administered in doses commonly used for supplementation (Leo \& Lieber 1999). Therefore, this study aimed to investigate the metabolic, biochemical and hepatic structural effects of the oral administration of $\beta$-carotene to $\mathrm{C} 57 \mathrm{BL} / 6$ mice exposed to two different doses of ethanol consumption. 


\section{MATERIALS AND METHODS}

\section{ANIMALS}

Thirty male C57BL/6 mice were used (Mus musculus), 50 days old, from the Chilean Public Health Institute. They were kept for 30 days in the Animal Facility of the Center of Excellence in Morphological and Surgical Studies (CEMyQ) at Universidad de La Frontera, Chile under standardized conditions and a $12 \mathrm{~h} / 12 \mathrm{hrs}$ light/ dark cycle, with $50 \%$ humidity and $22 \pm 2{ }^{\circ} \mathrm{C}$. During the experimental period, the mice were fed a standard laboratory diet (AIN-93M), following the guidelines established in the Guide for the Care and Use Laboratory Animals (Committee for the Update of the Guide for the Care and Use of Laboratory Animals, Institute for Laboratory Animal Research, Division on Earth and Life Studies \& National Research Council 2011). This study was approved by the Scientific Ethics Committee of the Universidad de La Frontera ( $\left.{ }^{\circ} 043 / 2016\right)$.

At the beginning of the experimental period, the mice were divided into six groups for four weeks under the following conditions: Control group (C): Group not exposed to alcohol or $\beta$-carotene; Low-dose alcohol group (LA): mice exposed to low-dose alcohol consumption ( $3 \% \mathrm{v} / \mathrm{v}$ ad libitum); Moderate-dose alcohol group (MA): mice exposed to moderate-dose alcohol consumption (7\% $\mathrm{v} / \mathrm{v}$ ad libitum); $\beta$-carotene group (B): mice exposed to the administration of $\beta$-carotene; Low-dose alcohol $+\beta$ carotene $(\mathrm{LA}+\mathrm{B})$ and; Moderate-dose alcohol $+\beta$-carotene $(\mathrm{MA}+\mathrm{B})$.

Liquid diet of chronic ethanol administration was given according the modified Lieber-DeCarli diet (Diao et al. 2020; Furuya et al. 2003). While, $\beta$-carotene was orally administered in a dose of $0.52 \mathrm{mgkg}^{-1}$ body weight/ day (Peng et al. 2013).

\section{METABOLIC ANALYSIS}

The body mass was measured at the beginning, during the whole experimental phase and at the end of the experiment phase with a scale (Radwag WTB 2000). During the experimental phase, the total caloric intake and consumption of food and liquids were measured each day. The total caloric intake was calculated according to the energy content of the different diets: $15.1 \mathrm{kJg}^{-1}$ for AIN-93; $23.4 \mathrm{kJmL}^{-1}$ of $100 \%$ ethanol and; $0.104 \mathrm{kJg}^{-1}$ by $\beta$-carotene (Furuya et al. 2003; Reeves et al. 1993; Treszczanowicz et al. 2003).

\section{BIOCHEMISTRY}

For the serum analyses, the serum was separated by centrifugation ( $3500 \mathrm{rpm}$ for $15 \mathrm{~min}$ ) and stored at -80 ${ }^{\circ} \mathrm{C}$ until analysis. The lipid profile was evaluated by quantifying the physiological concentrations of total cholesterol (CHOL-T) and triglycerides (TG). HDL-C was measured using a kinetic-colorimetric method (Bioclin System II, Quibasa, Belo Horizonte, Brazil). LDL-C was obtained from the Friedewald formula. The hepatic physiology was analyzed by means of the enzymatic activities of alanine aminotransferase (ALAT), aspartate aminotransferase (ASAT) and of gammaglutamyl transpeptidase (GGT) with its respective test (enzymatic method with automatic spectrophotometer, Bioclin System II, Quibasa, Belo Horizonte, Brazil). The biochemical analysis was performed by quantifying the physiological concentration of glucose through a colorimetric kit, whereas the insulin was quantified by means of an ELISA kit specific to mice (Millipore, Missouri, USA). The enzymatic activity of ALDH was also determined (enzymatic method with automatic spectrophotometer, Bioclin System II, Quibasa, Belo Horizonte, Brazil) with its respective kit for the analysis.

\section{HOMEOSTASIS MODEL ASSESSMENT OF B-CELL FUNCTION (HOMA-SS)}

The HOMA- $\beta$ index was calculated according to the following (1) (Matthews et al. 1985):

$$
\frac{\left[20 x \text { fasting insulin }\left(\frac{u U}{m L}\right)\right]}{\left[\text { fasting glucose }\left(\frac{m m o L}{L}\right)-3.5\right]}
$$

\section{HOMEOSTASIS MODEL ASSESSMENT OF INSULIN RESISTANCE (HOMA-IR)}

The HOMA-IR index was calculated according to the following (2) (Vogeser et al. 2007):

$$
\frac{\left[\text { fasting insulin }\left(\frac{u U}{m L}\right) \times \text { fasting glucose }\left(\frac{m m o L}{L}\right)\right]}{22.5}
$$

\section{PROCESSING AND STAINING OF LIVER}

Multiple sections of each liver were taken to get representative characteristics of each liver, considering the isotropic characteristics of the tissue. Next, they were fixed in buffered formalin $\left(1.27 \mathrm{molL}^{-1}\right.$ formaldehyde 
in $0.1 \mathrm{M}$ phosphate buffer $\mathrm{pH} 7.2$ ) at $4 \%$ for $48 \mathrm{~h}$, dehydrated, and embedded in Paraplast Plus (SigmaAldrich Co., St. Louis, MO, USA). Once the blocks were obtained, cuts were made $5 \mu \mathrm{m}$ thick in a microtome (Leica ${ }^{\circledR}$ RM2255). Then, five cuts were obtained from each block, which were stained with Hematoxylin and Eosin (H\&E) for their histological evaluation.

\section{STATISTICAL ANALYSIS}

The differences in the quantitative data were evaluated using the Kolmogorov-Smirnov test (normality test) and Levene's test (homoscedasticity test). The differences between the groups were analyzed with a one-way ANOVA, followed by Tukey's post-hoc HSD test or Dunnett's T3 test, as applicable. The P values were considered significant when they were $p<0.05\left(^{*}\right)$ and very significant at $\mathrm{p}<0.025\left(^{* *}\right)$ (IBM SPSS Statistics, Version 21, IBM Corp., Armonk, NY, USA).

\section{RESULTS}

\section{METABOLIC ANALYSIS}

Results of the BW change, food intake, ethanol intake and caloric intake are shown in Table 1 . BW changes of the $\mathrm{MA}+\mathrm{B}$ group was significantly higher than in the $\mathrm{C}$ and LA groups $(p<0.05)$. The food and ethanol intake in the $\mathrm{LA}+\mathrm{B}$ and $\mathrm{MA}+\mathrm{B}$ groups were significantly lower than the other groups $(p<0.05)$, and consequently $L A+B$ and $\mathrm{MA}+\mathrm{B}$ groups also showed reduced energy intake when compared to their counterparts LA and MA $(p<0.05)$.

TABLE 1. Metabolic analysis of male C57BL/6 mice exposed to ethanol consumption and oral supplementation with $\beta$-carotene

\begin{tabular}{|c|c|c|c|c|c|c|c|}
\hline \multicolumn{8}{|c|}{$\begin{array}{l}\text { Mean } \\
\text { SD }\end{array}$} \\
\hline & $\mathrm{C}$ & LA & MA & B & $\mathrm{LA}+\mathrm{B}$ & $\mathrm{MA}+\mathrm{B}$ & $P$ \\
\hline $\begin{array}{l}\Delta \text { Body weight } \\
(\mathrm{g})\end{array}$ & $1.9 \pm 0.9$ & $1.7 \pm 1.3$ & $6.1 \pm 3.9$ & $2.7 \pm 2.2$ & $2.6 \pm 0.9$ & $7.7 \pm 4.2^{\mathrm{ab}}$ & 0.001 \\
\hline Food intake $(\mathrm{g})$ & $3.8 \pm 0.6$ & $4.0 \pm 0.8$ & $4.2 \pm 1.1^{\mathrm{a}}$ & $3.9 \pm 0.7$ & $3.5 \pm 0.5^{\mathrm{abcd}}$ & $3.7 \pm 0.6^{c}$ & 0.001 \\
\hline $\begin{array}{l}\text { Liquid intake } \\
(\mathrm{mL})\end{array}$ & $4.7 \pm 2.5$ & $7.1 \pm 5.3^{\mathrm{a}}$ & $11.3 \pm 9.4^{\mathrm{ab}}$ & $4.1 \pm 1.8^{\mathrm{bc}}$ & $3.8 \pm 1.9^{\mathrm{bc}}$ & $4.4 \pm 2.3^{\mathrm{bc}}$ & 0.001 \\
\hline $\begin{array}{l}\text { Calories } \\
\text { consumed (kJ) }\end{array}$ & $61.0 \pm 9.4$ & $65.4 \pm 12.5$ & $68.6 \pm 18.6^{\mathrm{a}}$ & $62.0 \pm 11.3^{\mathrm{a}}$ & $58.0 \pm 8.7^{\mathrm{bc}}$ & $62.3 \pm 10.4^{c}$ & 0.001 \\
\hline
\end{tabular}

$\Delta$ Body weight is the difference between the final weight (after 4 weeks of treatment) and the initial weight. Foods, liquids and calories consumed were measured for the 4 experimental weeks (one measurement per day). ${ }^{a}$ Significant differences $(\mathrm{p}<0.05)$ with the C group. ${ }^{\mathrm{b}}$ Significant differences $(\mathrm{p}<0.05)$ with the LA group. ${ }^{\mathrm{c} S i g n i f i c a n t}$

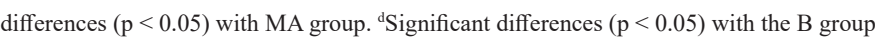

\section{BIOCHEMISTRY}

Biochemical analysis for insulin, glucose, EtOH and ALDH are shown in Figure 1. Results of Lipid profile for CHOL-T, HDL-C, LDL-C and TG are in Figure 2, and liver function tests like ALAT, ASAT and GGT in Figure 3. The analysis for HOMA- $\beta$ and HOMA-IR index is shown in Table 2. Briefly, the LA group showed reduced HDL-C levels and HOMA- $\beta$ coupled with increased glucose and EtOH levels compared to the $\mathrm{C}$ group. The MA group had higher glucose levels than $\mathrm{C}$ and LA, while ASAT was significantly reduced compared to the $\mathrm{C}$ group, and
GGT and HOMA- $\beta$ decreased in comparison with the LA group. The $\beta$-carotene supplementation enhanced the glucose levels and decreased GGT and HOMA- $\beta$ compared to the $\mathrm{C}$ group.

The LA + B group showed lower GGT and HOMA- $\beta$ than $\mathrm{C}$ group, whereas the $\mathrm{MA}+\mathrm{B}$ showed a high responsiveness to the $\beta$-carotene supplementation with reduced CHOL-T levels in comparison with the $\mathrm{LA}+\mathrm{B}$ group and reduced insulin, GGT and HOMA- $\beta$ when compared to the $\mathrm{C}$ group. Moreover, the $\mathrm{MA}+\mathrm{B}$ group showed higher glucose levels than the $\mathrm{C}$ group and higher ALDH levels than the MA group. 

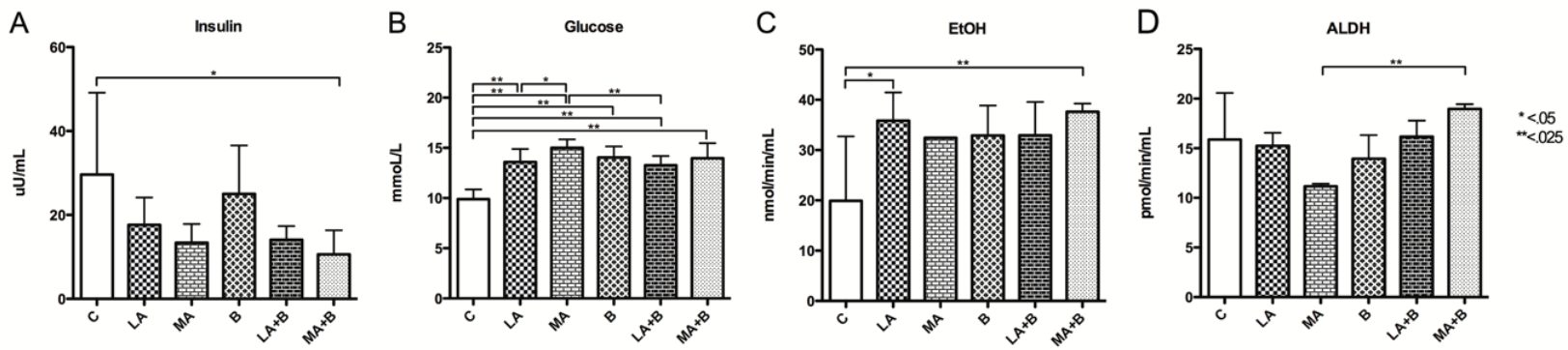

FIGURE 1. Biochemical analysis of male C57BL/6 mice exposed to ethanol consumption and $\beta$-carotene supplementation. Serum levels of insulin (A) and glucose (B). Ethanol dehydrogenase (C) and aldehyde dehydrogenase (D) activities. Values are mean $\pm \mathrm{SD}(\mathrm{n}=5)$. Differences were analyzed by one-way ANOVA
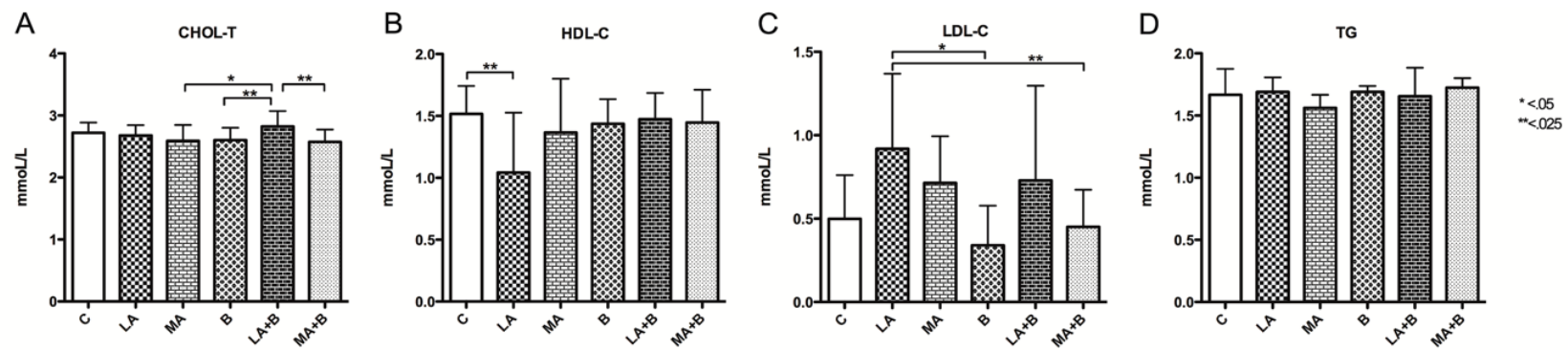

FIGURE 2. Lipid profile of male C57BL/6 mice exposed to ethanol consumption and oral supplementation with $\beta$-carotene. Total cholesterol (A), high-density lipoprotein cholesterol (B), low-density lipoprotein cholesterol (C) and triglycerides (D). Values are mean $\pm \mathrm{SD}(\mathrm{n}=5)$. Differences were analyzed by one-way ANOVA
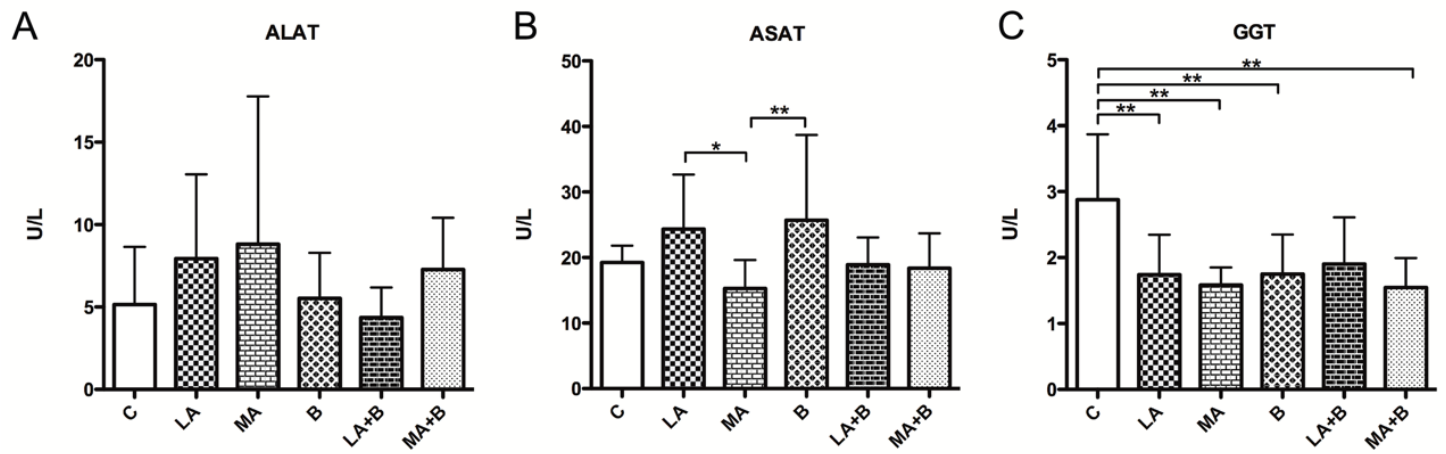

FIGURE 3. Liver function tests in male C57BL/6 mice exposed to ethanol consumption and oral supplementation with $\beta$-carotene. Alanine aminotransferase (A), aspartate aminotransferase (B) and gamma-glutamyl transpeptidase (C) activities. Values are mean $\pm \mathrm{SD}(\mathrm{n}=5)$. Differences were analyzed by one-way ANOVA 
TABLE 2. HOMA- $\beta$ and HOMA-IR index of male C57BL/6 mice exposed to ethanol consumption and oral supplementation with $\beta$-carotene

\begin{tabular}{cccccccc}
\hline \multicolumn{7}{c}{ Mean } \\
& \multicolumn{7}{c}{ SD } \\
\hline C & LA & MA & B & LA+B & MA+B & $P$ \\
HOMA- 3 & $93.5 \pm 49.2$ & $35.4 \pm 12.9^{\mathrm{a}}$ & $23.4 \pm 7.6^{\mathrm{a}}$ & $46.9 \pm 22.5^{\mathrm{a}}$ & $27.1 \pm 5.1^{\mathrm{a}}$ & $20.2 \pm 11.4^{\mathrm{a}}$ & $<0.001$ \\
HOMA-IR & $13.2 \pm 9.9$ & $10.6 \pm 4.1$ & $8.9 \pm 3.1$ & $15.8 \pm 7.2$ & $8.7 \pm 2.4$ & $6.7 \pm 3.5$ & 0.098 \\
\hline
\end{tabular}

aSignificant differences $(p<0.05)$ with the $\mathrm{C}$ group

\section{LIVER STRUCTURE}

The control group presented a well-preserved hepatic parenchyma, without noticeable hepatic steatosis (Figure 4(A)). In contrast, the group that received a low dose of alcohol showed an adverse hepatic remodeling with enlarged hepatocytes, slightly microvesicular steatosis and isolated inflammatory foci comprised mainly of polymorphonuclear cells (Figure 4(B)). The moderate alcohol dose elicited hepatocyte ballooning with numerous macrovesicular and microvesicular steatosis vesicles, compromising the hepatocyte cytoarchitecture. In addition, some inflammatory foci (polymorphonuclear cells) were found mainly in the periportal areas (Figure $4(C)$ ). $\beta$-carotene supplementation in the group that did not take alcohol caused hepatic steatosis, but the liver tissue structure was not damaged (Figure 4(D)). $\beta$-carotene supplementation improved the hepatic parenchyma in animals that received the low alcohol dose, which showed normal-sized hepatocytes with little steatosis (Figure $4(E)$ ). The $\beta$-carotene supplementation alleviated the structural damage in the liver of the MA+B group, showing reduced hepatocyte ballooning and fewer lipid droplets compared to the MA group (Figure 4(F)).
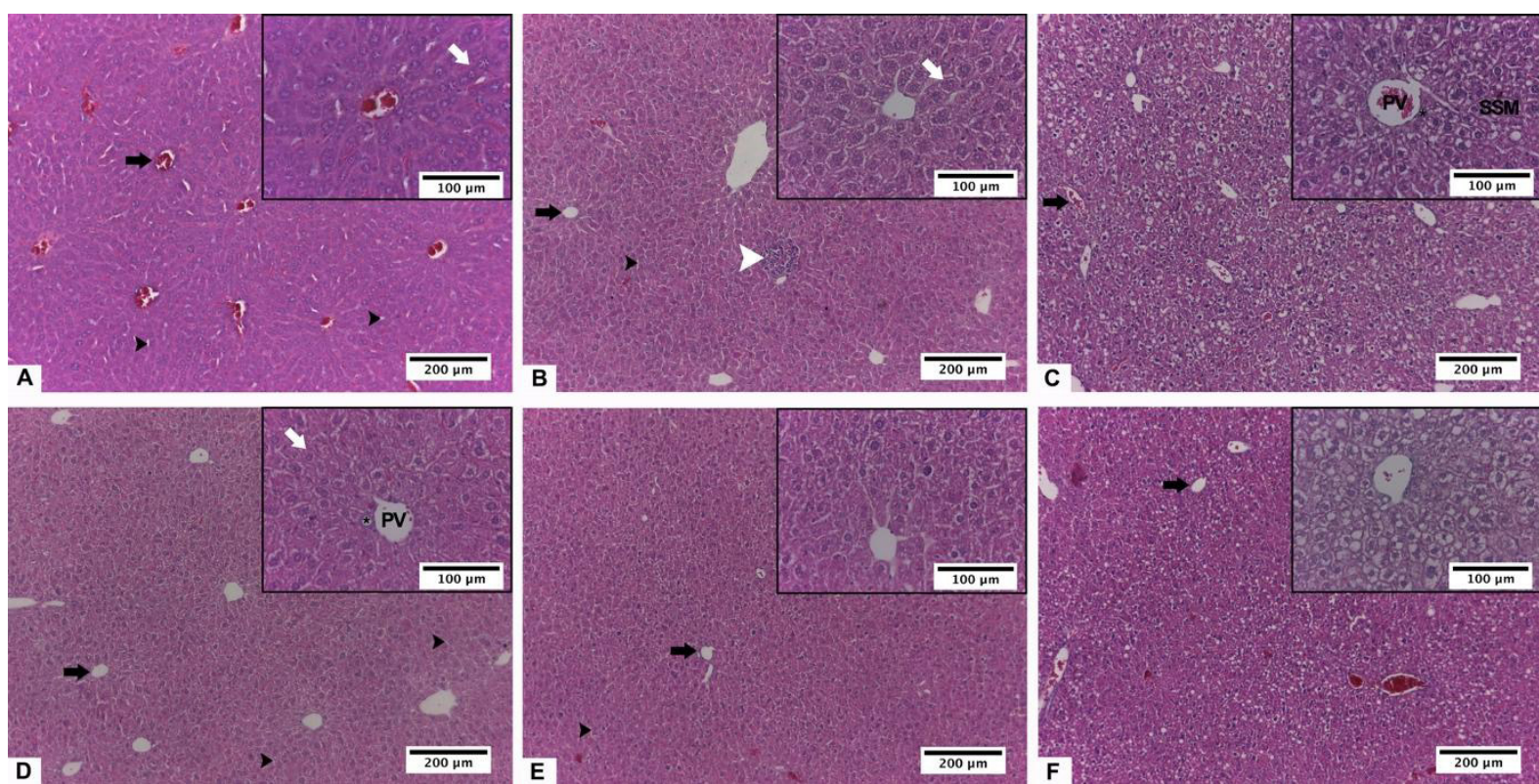

FIGURE 4. Liver of male C57BL/6 mice. Hepatic architecture was observed in groups: C (A), Low-dose alcohol (B), Moderate-dose alcohol (C), $\beta$-carotene (D), Low-dose alcohol $+\beta$ carotene $(\mathrm{E})$ and Moderate-dose alcohol $+\beta$-carotene $(\mathrm{F})$. The shows differences in hepatocytes and periportal areas in higher magnification. The figure shows the central vein (black arrow), cords of hepatocytes radiating peripherally (white arrow), sinusoidal spaces are present between the hepatocytes (black arrowhead), inflammatory infiltrate (white arrowhead), stellate sinusoidal macrophages (SSM) and, portal areas consisting of portal vein (PV) and bile ductile (asterisk) 


\section{DISCUSSION}

The results show compelling evidence that $\beta$-carotene supplementation can alleviate metabolic and histological constraints stemming from chronic exposure to ethanol in mice. It seems that the proposed treatment was more effective in animals exposed to moderate alcohol intake and, therefore, that showed more noticeable features of ALD.

The HOMA-IR is regarded as a simple, inexpensive, and reliable surrogate measure of insulin resistance, while the HOMA- $\beta$ index has been determined to be a good measure of $\beta$-cell function (Wallace et al. 2004). Our results show that groups exposed to chronic ethanol consumption in low and moderate doses exhibit a lower HOMA-IR index (Table 2) and improved insulin sensitivity, which agrees with what has been described previously. However, the HOMA- $\beta$ index in mice exposed to chronic ethanol consumption differs from what has been mentioned.

The results shown in Table 1 could be explained due to the fact that alcohol stimulates the appetite (Hetherington et al. 2001), promoting food intake and increasing serum glucose levels (Figure 1(B)). These results are corroborated by our metabolic analysis where animals exposed to ethanol consumption showed increased food intake $(\mathrm{p}<0.001)$.

Several results have described a relation between ethanol consumption and lipid concentrations. Most epidemiological studies report a J-shaped curve, whereby mild to moderate ethanol consumption poses less risk for adverse cardiovascular events and overall mortality than abstainers, where heavy drinkers have shown an increased risk (Brien et al. 2011). While our results showed a lower serum level of HDL-C in animals subjected to a low ethanol dose compared to the $\mathrm{C}$ group $(1.043 \pm 0.484 ; \mathrm{p}$ $=0.037)$. No differences between the $\mathrm{C}$ group and the other experimental groups were observed (Figure 2B). These discrepancies may be related to the type of sample used, the variability of the models, the alcohol type, as well as the form and time of alcohol administration, among other factors. However, the mechanisms by which alcohol influences HDL-C are not fully understood. In effect, various mechanisms have been proposed, including an increased transport rate of lipoproteins and increased lipoprotein lipase activity (Silva et al. 2000).

Biochemical tests can be useful to determining the toxic effects and health wellness (Ferreira et al. 2007). It has been described that hepatic damage could be observed after 4 and 12 weeks of ethanol treatment, which is evidenced by higher levels of hepatic enzyme markers and malondialdehyde (Mirzaei et al. 2015). In effect, a combination of clinical laboratory findings aided better detection and exclusion of alcoholism in men (Stamm et al. 1984). For alcoholics, abnormal values for two or more of the five parameters ALAT, ASAT, GGT and creatinine gave a diagnostics sensitivity of $85 \%$ and a diagnostic specificity of $64 \%$. Likewise, elevated ALAT and ASAT levels have been described as a general indicator of tissue and organ damage caused by alcohol, viruses, infections, drugs or toxins (Agarwal \& Goedde 2012). However, there is neither a correlation between ALAT and total ASAT and alcohol consumption nor a correlation with the duration of drinking (Morgan et al. 1981). Although our results showthe existence of liver damage produced by ethanol intake, where differences between the mean of all groups in ALAT $(p=0.157)$, ASAT $(p=0.008)$ and GGT $(\mathrm{p}<0.001)$ were observed, it is not always possible to establish a relationship between the consumption patterns, the period of consumption and the enzymatic profile (Figure 3).

Alcohol metabolism increases in chronic alcoholics (Lieber \& DeCarli 1970). This is usually considered one of the major causes of alcohol-induced liver injury (Zakhari \& Li 2007). The liver is vital to alcohol metabolism in the body, and more than $85 \%$ of ingested ethanol is metabolized in the liver (Wen et al. 2016). The primary alcohol metabolic enzymes including cytosolic EtOH, mitochondrial ALDH, and cytochrome P450 2E1 (CYP2E1). The alcohol is decomposed into acetaldehyde by EtOH and subsequently into acetate by ALDH. Thus, severe ethanol-induced liver injury might be associated with the activities of EtOH and ALDH (Yoo et al. 2011).

Ethanol treatment decreases cell viability in rat hepatocytes via induced oxidative stress (Peng et al. 2010). Previous studies have proposed increased production in the group of enzymes plays an active role in the catabolism of alcohol after long-term alcohol consumption. In effect, increased tolerance to alcohol has been linked to an increased production in $\mathrm{EtOH}$, ALDH, CYP2E1 or ARNm de 2E1 (Jin et al. 2013). Likewise, it has been described that $\beta$-carotene decreases oxidative stress and prevents ethanol-induced cell death by inhibiting caspase- 9 and caspase- 3 expression (Peng et al. 2010). Our results support the previous findings, where an increase in plasma EtOH levels was found in all groups exposed to chronic ethanol consumption with or without $\beta$-carotene supplementation $(p=0.026)$ (Figure 1(C)) (Kishimoto et al. 1995). 
Chronic ethanol exposure as increasing ALDH activity in mice, suggesting physiological tolerance (Panes et al. 1993). However, while animals exposed to chronic ethanol consumption and oral $\beta$-carotene administration had an increase in plasma concentrations of ALDH, a decrease of this enzyme had been shown in groups without supplementation $(\mathrm{p}=0.005)$ (Figure 1(D)). Previous reports have been demonstrated that patients with chronic liver disease showed lower ALDH activity than the controls (Panes et al. 1993). In fact, some studies found a marked decrease in the total ALDH in patients with advanced liver disease, where the decrease was more marked in patients with greater fibrosis and hepatic damage (Vidal et al. 1998). These findings could be explained because while $\beta$-carotene prevents ethanol-induced GSH depletion and lipid peroxidation (Peng et al. 2010), in groups without supplementation, acetaldehyde dehydrogenase could be inhibited by the production of ethanol-induced ROS. In effect, acute and chronic ethanol exposure increases the levels of ROS in rat liver cells (Bailey \& Cunningham 2002). In this sense, ethanol-induced ROS have been shown to inhibit ALDH1 and ALDH2 in rat liver cells via S-nitrosylation (Moon et al. 2007).

Hepatic steatosis is a primary response to the chronic consumption of ethanol in over $90 \%$ of individuals (Gao $\&$ Bataller 2011). The evidence obtained over the past decade has demonstrated that the mechanisms by which ethanol produces steatosis are likely to be multifactorial, involving effects on hepatic lipid metabolism, hypoxia, oxidative stress and lipid peroxidation (Sozio \& Crabb 2008). In accordance with this, our results showed enlarged hepatocytes and slightly microvesicular steatosis in the LA group (Figure 4(B)), and hepatocyte ballooning with numerous macrovesicular and microvesicular steatosis vesicles in the MA group (Figure 4(C)). Isolated inflammatory foci mainly composed of polymorphonuclear cells in both groups were observed. These results agree with previous studies, where alcoholic steatohepatitis (ASH) has been defined by the presence of fatty liver, inflammatory infiltrate (which mainly consists of polymorphonuclear cells) and hepatocellular damage (Bataller et al. 2011).

Antioxidant micronutrients, such as vitamins and carotenoids, exist in abundance in fruits and vegetables and have been known to contribute to the body's defense against reactive oxygen species (Stanner et al. 2004). It is known that antioxidant vitamins and carotenoids are reduced in several liver diseases, such as hepatitis and cirrhosis (Van De Casteele et al. 2002).
We described that $\beta$-carotene supplementation improved the hepatic parenchyma in animals, showing normalsized hepatocytes with little steatosis in the $\mathrm{LA}+\mathrm{B}$ group (Figure $4(E)$ ). In the MA+B group, the $\beta$-carotene supplementation also appears to lessen the structural damage in the liver, showing fewer lipid droplets than the MA group (Figure 4(F)). In fact, many studies have reported that carotenoids, such as $\beta$-carotene, lycopene, lutein, and $\beta$-kryptoxanthin, have antioxidant effects against lipid peroxidation in rat liver (Whittaker et al. 1996).

Our results show that the $\beta$-carotene protects against the progression of simple steatosis to more harmful liver diseases. The majority of the retinoid reservoir in the liver is found within the hepatic stellate cells (HSCs) in the form of retinyl esters, and the depletion of retinoids in the HSCs triggers their activation, favoring the progression to steatohepatitis. Previous studies have shown that retinoic supplementation altered the composition of lipid droplets within the HSCs and may be an important approach to avoid the progression of ALD (Blaner et al. 2009). In heavy drinkers', alternative alcohol-metabolic pathways are engaged following excessive alcohol consumption due to the zero-order kinetics of alcohol metabolism. The ensuing increase in acetaldehyde production puts stress on microsomal re-oxidation pathways which utilize more oxygen and ATP by Lieber (1988) to recover nicotinamide adenine dinucleotide, thereby perpetuating the hyperdynamic metabolism by increasing energy utilization (Kamran et al. 2020). For this, $\beta$-carotene effects over heavy alcohol intake must be determined in future studies.

As chronic ethanol consumption depletes the hepatic vitamin A reservoir, carotenoid supplementation exerts antioxidant effects that results in beneficial hepatic remodeling and reduced fibrosis (Firdous et al. 2011). Another study showed that supplementation with the carotenoid lutein exerted hepatoprotective effects through antioxidant mechanisms in three different mouse models of hepatic injury: exposure to ethanol, paracetamol 20\% and carbon tetrachloride (Sindhu et al. 2010). However, attention must be given to the dose used, as high doses seem to exacerbate the adverse histological features, whereas low doses seem to be protective. The dose used here seems to be safe (Stice \& Wang 2013).

\section{CONCLUSION}

A variety of natural and synthetic antioxidants are currently available, and most of their mechanisms of action are known. However, the mechanisms through which 
ethanol and antioxidants intervene in ALD are not yet clear. Our study presents, from a physiological perspective, the prevention of alcoholic liver disease alcohol intake and oral supplementation with $\beta$-carotene. Thus, it is highly recommended alcoholics to take $\beta$-carotene supplements to prevent alcoholic liver disease and improve their health. However, some limitations should be considered. First, only one dose of $\beta$-carotene was investigated in this study, being able to use other concentrations as well. Second, while the effect of low and moderate doses of alcohol have been analyzed in the present study, it could also have studied the effect on high doses. Future studies should assess the metabolic and physiological effects of ethanol-induced hepatic steatosis, describing the signaling pathways involved and clearly indicating the exposure time and the amount and type of alcohol ingested.

\section{ACKNOWLEDGEMENTS}

This Project was funded by Universidad de La Frontera, DIUFRO DI20-0003; CONICYT-PCHA/Doctorado Nacional/2015-21150991 and the Canadian Institutes for Health Research awarded to Dr. Adeli.

\section{REFERENCES}

Agarwal, D. \& Goedde, H. 2012. Alcohol Metabolism, Alcohol Intolerance, and Alcoholism: Biochemical and Pharmacogenetic Approaches. Luxemburgo: Springer Science \& Business Media.

Albanes, D., Heinonen, O.P., Taylor, P.R., Virtamo, J., Edwards, B.K., Rautalahti, M., Hartman, A.M., Palmgren, J., Freedman, L.S., Haapakoski, J., Barrett, M.J., Pietinen, P., Malila, N., Tala, E., Liippo, K., Salomaa, E.R., Tangrea, J.A., Teppo, L., Askin, F. B., Taskinen, E., Erozan, Y., Greenwald, P. \& Huttunen J.K. 1996. Alpha-tocopherol and beta-carotene supplements and lung cancer incidence in the alphatocopherol, beta-carotene cancer prevention study: Effects of base-line characteristics and study compliance. Journal of the National Cancer Institute 88(21): 1560-1570.

Albano, E. 2008. Oxidative mechanisms in the pathogenesis of alcoholic liver disease. Molecular Aspects of Medicine 29(1-2): 9-16.

Alpha-Tocopherol, Beta Carotene Cancer Prevention Study Group. 1994. The effect of vitamin $\mathrm{E}$ and beta carotene on the incidence of lung cancer and other cancers in male smokers. The New England Journal of Medicine 330(15): 1029-1035.

Bailey, S.M. \& Cunningham, C.C. 2002. Contribution of mitochondria to oxidative stress associated with alcoholic liver disease. Free Radical Biology and Medicine 32(1): 11-16.

Bataller, R., Rombouts, K., Altamirano, J. \& Marra, F. 2011. Fibrosis in alcoholic and nonalcoholic steatohepatitis. Best
Practice \& Research: Clinical Gastroenterology 25(2): 231-244.

Bjelakovic, G., Gluud, L.L., Nikolova, D., Bjelakovic, M., Nagorni, A. \& Gluud, C. 2011. Antioxidant supplements for liver diseases. Cochrane Database Systematic Reviews 3: Article ID. CD007749.

Blaner, W.S., O’Byrne, S.M., Wongsiriroj, N., Kluwe, J., D'Ambrosio, D.M., Jiang, H., Schwabe, R.F., Hillman, E.M.C., Piantedosi, R. \& Libien, J. 2009. Hepatic stellate cell lipid droplets: A specialized lipid droplet for retinoid storage. Biochimica et Biophysica Acta 1791(6): 467-473.

Brien, S.E., Ronksley, P.E., Turner, B.J., Mukamal, K.J. \& Ghali, W.A. 2011. Effect of alcohol consumption on biological markers associated with risk of coronary heart disease: Systematic review and meta-analysis of interventional studies. British Medical Journal 342: d636.

Chang, P., Cheng, E., Brooke, S. \& Sapolsky, R. 2005. Marked differences in the efficacy of post-insult gene therapy with catalase versus glutathione peroxidase. Brain Research 1063(1): 27-31.

Clugston, R.D. \& Blaner, W.S. 2012. The adverse effects of alcohol on vitamin A metabolism. Nutrients 4(5): 356-371.

Committee for the Update of the Guide for the Care and Use of Laboratory Animals, Institute for Laboratory Animal Research, Division on Earth and Life Studies \& National Research Council. 2011. Guide for the Care and Use of Laboratory Animals. 8th ed. Washington: The National Academies Press.

Diao, Y., Nie, J., Tan, P., Zhao, Y., Zhao, T., Tu, J., Ji, H., Cao, Y., Wu, Z., Liang, H., Huang, H., Li, Y., Gao, X. \& Zhou, L. 2020. Long-term low-dose ethanol intake improves healthspan and resists high-fat diet-induced obesity in mice. Aging 12(13): 13128-13146.

Dixon, Z.R., Shie, F.S., Warden, B.A., Burri, B.J. \& Neidlinger, T.R. 1998. The effect of a low carotenoid diet on malondialdehydethiobarbituric acid (MDA-TBA) concentrations in women: A placebo-controlled double-blind study. Journal of the American College of Nutrition 17(1): 54-58.

Dixon, Z.R., Burri, B.J., Clifford, A., Frankel, E.N., Schneeman, B.O., Parks, E., Keim, N.L., Barbieri, T., Wu, M.M., Fong, A.K., Kretsch, M.J., Sowell, A.L. \& Erdman, J.W. 1994 Effects of a carotene-deficient diet on measures of oxidative susceptibility and superoxide dismutase activity in adult women. Free Radical Biology and Medicine 17(6): 537-544.

Fernandez-Checa, J.C. \& Kaplowitz, N. 2005. Hepatic mitochondrial glutathione: Transport and role in disease and toxicity. Toxicology and Applied Pharmacology 204(3): 263-273.

Ferreira, J., Hawkins, A. \& Bricker, S. 2007. Management of productivity, environmental effects and profitability of shellfish aquaculture - the Farm Aquaculture Resource Management (FARM) model. Aquaculture 264(1-4): 160174.

Firdous, A., Sindhu, E. \& Kuttan, R. 2011. Hepato-protective potential of carotenoid meso-zeaxanthin against paracetamol, 
$\mathrm{CCl} 4$ and ethanol induced toxicity. Indian Journal of Experimental Biology 49(1): 44-49.

Furuya, D., Binsack, R. \& Machado, U. 2003. Low ethanol consumption increases insulin sensitivity in Wistar rats. Brazilian Journal of Medical and Biological Research 36(1): 125-130.

Gao, B. \& Bataller, R. 2011. Alcoholic liver disease: Pathogenesis and new therapeutic targets. Gastroenterology 141(5): 15721585.

Grune, T., Lietz, G., Palou, A., Ross, A.C., Stahl, W., Tang, G., Thurnham, D., Yin, S. \& Biesalski, H.K. 2010. Beta-carotene is an important vitamin A source for humans. The Journal of Nutrition 140(12): 2268S-2285S.

Hetherington, M.M., Cameron, F., Wallis, D.J. \& Pirie, L.M. 2001. Stimulation of appetite by alcohol. Physiology \& Behavior 74(3): 283-289.

Institute of Medicine, Food and Nutrition Board. 2001. Dietary Reference Intakes for Vitamin A, Vitamin K, Arsenic, Boron, Chromium, Copper, Iodine, Iron, Manganese, Molybdenum, Nickel, Silicon, Vanadium, and Zinc. Washington, DC: National Academy Press.

Jin, M., Ande, A., Kumar, A. \& Kumar, S. 2013. Regulation of cytochrome P450 2e1 expression by ethanol: Role of oxidative stress-mediated pkc/jnk/sp1 pathway. Cell Death \& Disease 4(3): e554.

Kamran, U., Towey, J., Khanna, A., Chauhan, A., Rajoriya, N. \& Holt, A. 2020. Nutrition in alcohol-related liver disease: Physiopathology and management. World Journal of Gastroenterology 26(22): 2916-2930.

Kishimoto, R., Fujiwara, I., Kitayama, S., Goda, K. \& Nakata, Y. 1995. Changes in hepatic enzyme activities related to ethanol metabolism mice in following chronic ethanol administration. Journal of Nutritional Science and Vitaminology 41(5): 527-543.

Leo, M.A. \& Lieber, C.S. 1999. Alcohol, vitamin A, and betacarotene: Adverse interactions, including hepatotoxicity and carcinogenicity. The American Journal of Clinical Nutrition 69(6): 1071-1085.

Leo, M.A., Kim, C., Lowe, N. \& Lieber, C.S. 1992. Interaction of ethanol with beta-carotene: Delayed blood clearance and enhanced hepatotoxicity. Hepatology 15(5): 883-891.

Lieber, C. \& DeCarli, L. 1970. Hepatic microsomal ethanoloxidizing system. Journal of Biological Chemistry 245(10): 2505-2512.

Lieber, C.S. 1988. The influence of alcohol on nutritional status. Nutrition Reviews 46(7): 241-254.

Lin, W.T., Huang, C.C., Lin, T.J., Chen, J.R., Shieh, M.J, Peng, H.C., Yang, S.C. \& Huang, C.Y. 2009. Effects of betacarotene on antioxidant status in rats with chronic alcohol consumption. Cell Biochemistry and Function 27(6): 344350 .

Lin, Y., Burri, B.J., Neidlinger, T.R., Muller, H.G., Dueker, S.R. \& Clifford, A. 1998. Estimating the concentration of betacarotene required for maximal protection of low-density lipoproteins in women. The American Journal of Clinical Nutrition 67(5): 837-845.

Matthews, D.R., Hosker, J.P., Rudenski, A.S., Naylor, B.A., Treacher, D.F. \& Turner, R.C. 1985. Homeostasis model assessment: Insulin resistance and $\beta$-cell function from fasting plasma glucose and insulin concentrations in man. Diabetologia 28(7): 412-419.

Mirzaei, A., Mirzaei, N. \& Alamdari, A. 2015. Effects of chronic ethanol consumption on biochemical parameters and oxidative stress on rat. Indian Journal of Science and Technology 8(25): 1-5.

Moon, K.H., Abdelmegeed, M.A. \& Song, B.J. 2007. Inactivation of cytosolic aldehyde dehydrogenase via S-nitrosylation in ethanol-exposed rat liver. FEBS Letters 581(21): $3967-$ 3972.

Morgan, M., Colman, J. \& Sherlock, S. 1981. The use of a combination of peripheral markers for diagnosing alcoholism and monitoring for continued abuse. Alcohol and Alcoholism 16(4): 167-177.

Nieto, N. 2007. Ethanol and fish oil induce NFкB transactivation of the collagen $\alpha 2(\mathrm{I})$ promoter through lipid peroxidation - driven activation of the PKC-PI3K-Akt pathway. Hepatology 45(6): 1433-1445.

Panes, J., Caballeria, J., Guitart, R., Pares, A., Soler, X., Rodamilans, M., Navasa, M., Pares, X., Bosch, J. \& Rodes, J. 1993. Determinants of ethanol and acetaldehyde metabolism in chronic alcoholics. Alcoholism: Clinical and Experimental Research 17(1): 48-53.

Peng, H.C., Chen, Y.L., Yang, S.Y., Ho, P.Y., Yang, S.S., Hu, J.T. \& Yang, S.C. 2013. The antiapoptotic effects of different doses of $\beta$-carotene in chronic ethanol-fed rats. Hepatobiliary Surgery and Nutrition 2(3): 132.

Peng, H.C., Chen, J.R., Chen, Y.L., Yang, S.C. \& Yang, S.S. 2010. B-Carotene exhibits antioxidant and anti-apoptotic properties to prevent ethanol-induced cytotoxicity in isolated rat hepatocytes. Phytotherapy Research 24(S2): S183-S189.

Reeves, P.G., Nielsen, F.H. \& Fahey, G.C. 1993. AIN-93 purified diets for laboratory rodents: Final report of the American institute of nutrition ad hoc writing committee on the reformulation of the AIN-76A rodent diet. Journal of Nutrition 123: 1939-1951.

Ronis, M.J., Korourian, S., Blackburn, M.L., Badeaux, J. \& Badger, T.M. 2010. The role of ethanol metabolism in development of alcoholic steatohepatitis in the rat. Alcohol 44(2): 157-169.

Ross, C.A. 2010. Encyclopedia of Dietary Supplements. 2nd ed. London, New York: Informa Healthcare.

Sandoval, C., Vásquez, B., Souza-Mello, V., Adeli, K., Mandarimde-Lacerda, C. \& del Sol, M. 2019. Morphoquantitative effects of oral $\beta$-carotene supplementation on liver of $\mathrm{C} 57 \mathrm{BL} / 6$ mice exposed to ethanol consumption. International Journal of Clinical and Experimental Pathology 12(5): 1713-1722. 
Schwartz, J.M. \& Reinus, J.F. 2012. Prevalence and natural history of alcoholic liver disease. Clinical Liver Disease 16(4): 659-666.

Silva, E., Foster, D., Harper, M., Seidman, C., Smith, J., Breslow, J. \& Brinton, E. 2000. Alcohol consumption raises HDL cholesterol levels by increasing the transport rate of apolipoproteins A-I and A-II. Circulation 102(19): $2347-$ 2352.

Sindhu, E.R., Firdous, A.P., Preethi, K.C. \& Kuttan, R. 2010. Carotenoid lutein protects rats from paracetamol-, carbon tetrachloride-and ethanol-induced hepatic damage. Journal of Pharmacy and Pharmacology 62(8): 1054-1060.

Solomons, N.W. 2006. Present Knowledge in Nutrition. 9th ed. Washington: International Life Sciences Institute.

Sozio, M. \& Crabb, D.W. 2008. Alcohol and lipid metabolism. American Journal of Physiology - Endocrinology and Metabolism 295(1): E10-E16.

Stamm, D., Hansert, E. \& Feuerlein, W. 1984. Detection and exclusion of alcoholism in men on the basis of clinical laboratory findings. Journal of Clinical Chemistry and Clinical Biochemistry 22: 79-96.

Stanner, S.A., Hughes, J., Kelly, C.N.M. \& Buttriss, J. 2004. A review of the epidemiological evidence for the 'antioxidant hypothesis'. Public Health Nutrition 7(3): 407-422.

Stice, C.P. \& Wang, X.D. 2013. Carotenoids and alcoholic liver disease. Hepatobiliary Surgery and Nutrition 2(5): 244-247.

Takeda, S., Bando, N. \& Yamanishi, R. 2008. Ingested $\beta$-carotene enhances glutathione level and up-regulates the activity of cysteine cathepsin in murine splenocytes. Bioscience, Biotechnology, and Biochemistry 72(6): 1595-1600.

Treszczanowicz, T., Kasprzycka-Guttman, T. \& Treszczanowicz, A.J. 2003. Solubility of $\beta$-carotene in binary solvents formed by some hydrocarbons with dibutyl ether and 1,2-dimethoxyethane. Journal of Chemical \& Engineering Data 48(6): 1517-1520.

Van De Casteele, M., Zaman, Z., Zeegers, M., Servaes, R., Fevery, J. \& Nevens, F. 2002. Blood antioxidant levels in patients with alcoholic liver disease correlate with the degree of liver impairment and are not specific to alcoholic liver injury itself. Alimentary Pharmacology \& Therapeutics 16(5): 985-992.

Vidal, F., Toda, R., Gutiérrez, C., Broch, M., Fernández-Muixí, F., Lorenzo, A. \& Richart, C. 1998. Influence of chronic alcohol abuse and liver disease on hepatic aldehyde dehydrogenase activity. Alcohol 15(1): 3-8.

Vogeser, M., König, D., Frey, I., Predel, H.G., Parhofer, K.G. \& Berg, A. 2007. Fasting serum insulin and the homeostasis model of insulin resistance (HOMA-IR) in the monitoring of lifestyle interventions in obese persons. Clinical Biochemistry 40(13-14): 964-968.

Wallace, T.M., Levy, J.C. \& Matthews, D.R. 2004. Use and abuse of HOMA modeling. Diabetes Care 27(6): 1487-1495.
Wen, D.C., Hu, X.Y., Wang, Y.Y., Luo, J.X., Lin, W., Jia, L.Y. \& Gong, X.Y. 2016. Effects of aqueous extracts from Panax ginseng and Hippophae rhamnoides on acute alcohol intoxication: An experimental study using mouse model. Journal of Ethnopharmacology 192: 67-73.

Whittaker, P., Wamer, W.G., Chanderbhan, R.F. \& Dunkel, V.C. 1996. Effects of $\alpha$-tocopherol and $\beta$-carotene on hepatic lipid peroxidation and blood lipids in rats with dietary iron overload. Nutrition and Cancer 25: 119-128.

Yoo, Y., Jung, E., Kang, H., Choi, I., Choi, K. \& Jeung, E. 2011. The sap of Acer okamotoanum decreases serum alcohol levels after acute ethanol ingestion in rats. International Journal of Molecular Medicine 28(4): 489-495.

Zakhari, S. \& Li, T.K. 2007. Determinants of alcohol use and abuse: Impact of quantity and frequency patterns on liver disease. Hepatology 46(6): 2032-2039.

Cristian Sandoval*

Escuela de Tecnología Médica

Facultad de Salud

Universidad Santo Tomás

Osorno

ChileCristian Sandoval*

Departamento de Ciencias Preclínicas

Facultad de Medicina

Universidad de la Frontera

Temuco

Chile

Bélgica Vásquez

Facultad de Ciencias de La Salud

Universidad de Tarapacá, Arica

Chile

Adriana Vasconcellos

Departamento de Ciencias Básicas

Facultad de Medicina

Universidad de La Frontera, Temuco

Chile

Vanessa Souza-Mello \& Carlos Mandarim-de-Lacerda

Laboratorio de Morfometría

Metabolismo y Enfermedades Cardiovasculares

Centro Biomédico, Instituto de Biología

Universidade do Estado do Rio de Janeiro

Rio de Janeiro

Brasil

Khosrow Adeli

Molecular Medicine, Research Institute

The Hospital for Sick Children

University of Toronto

Toronto, ON

Canada 
Mariano del Sol

Centro de Excelencia en Estudios Morfológicos y Quirúrgicos (CEMyQ)

Universidad de La Frontera, Temuco

Chile
*Corresponding author; email: cristian.sandoval@ufrontera.cl

Received: 18 March 2021

Accepted: 27 April 2021 